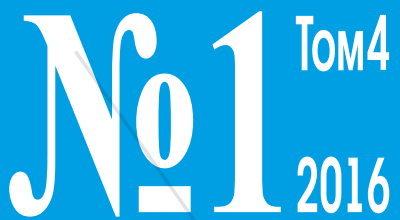

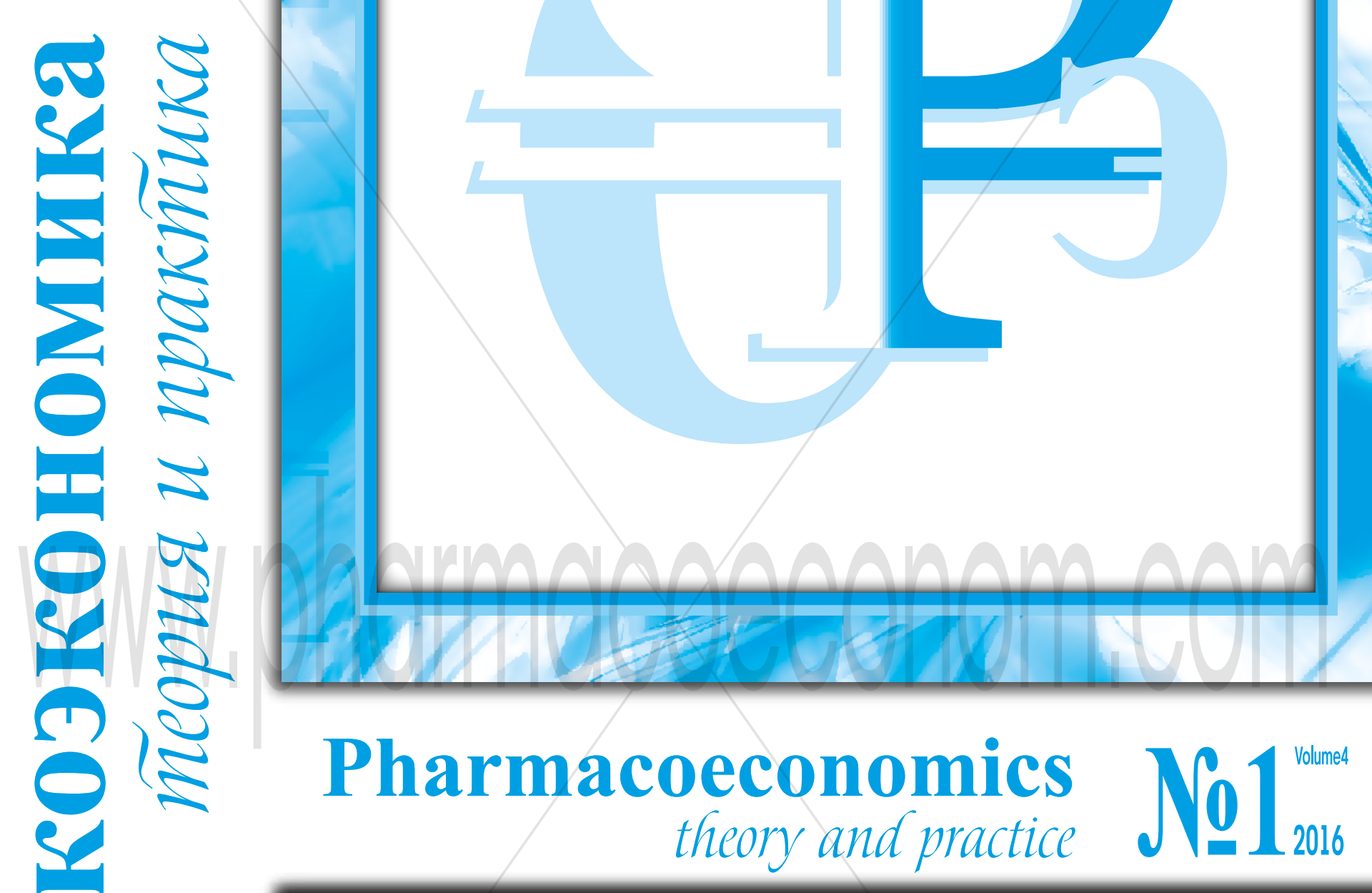

$\square$ МЕТОДОЛОГИЧЕСКИЕ ОСНОВЫ ФАРМАКОЭКОНОМИЧЕСКОГО МОДЕЛИРОВАНИЯ

$\square$ РЕЗУЛЬТАТЫ РОССИЙСКИХ ФАРМАКОЭКОНОМИЧЕСКИХ ИССЛЕДОВАНИЙ

口 МАТЕРИАЛЫ Х НАЦИОНАЛЬНОГО КОНГРЕССА С МЕЖДУНАРОДНЫМ УЧАСТИЕМ «РАЗВИТИЕ ФАРМАКОЭКОНОМИКИ И ФАРМАКОЭПИДЕМИОЛОГИИ В РОССИЙСКОЙ ФЕДЕРАЦИИ» 4-5 апреля 2016 г., г. Нижний Новгород 


\title{
МОНИТОРИНГ РОЗНИЧНЫХ ПРОДАЖ ПЕРОРАЛЬНЫХ АНТИКОАГУЛЯНТНЫХ ПРЕПАРАТОВ В Г. ВОЛГОГРАДЕ
}

\author{
RETAIL SALES MONITORING OF ORAL ANTICOAGULANTS IN \\ VOLGOGRAD
}

Горбатенко В.С., Шаталова О.В., Маслаков А.С.

Gorbatenko V.S., Shatalova O.V., Maslakov A.S.

\begin{abstract}
ГБОУ ВПО Волгоградский государственный медииинский университет Минздрава России, 2. Волгоград

State Budgetary Educational Institution of Higher Professional Education of the Volgograd State Medical University of the Ministry of Health of the Russia, Volgograd
\end{abstract}

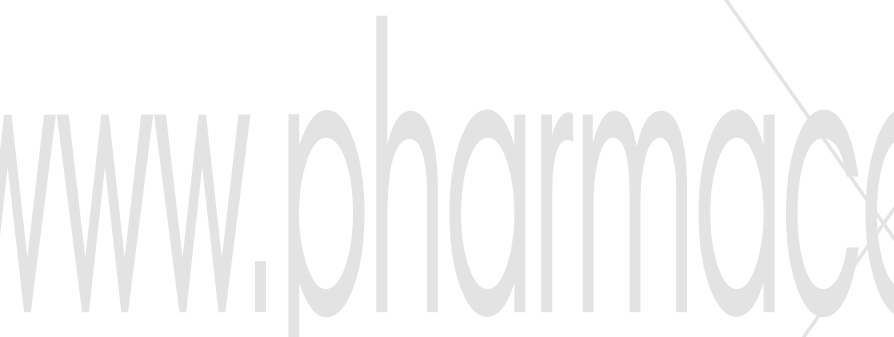

Ключевые слова: варфарин, дабигатран, апиксабан, ривароксабан.

Введение: фармацевтический рынок является системой обращения лекарственных средств и изделий медицинского назначения, которая удовлетворяет потребности населения в выздоровлении и поддержании здоровья и распределяет лекарственные средства на основе рыночной конкуренции с учетом их социальной значимости.

Рынок пероральных антикоагулянтов на протяжении многих десятилетий был представлен антагонистами витамина К, в частности основным его представителем - варфарином. Однако с 2009 г. в Российской Федерации были зарегистрированы новые пероральные антикоагулянты (дабигатрана этексилат и ривароксабан, а с 2012 г. апиксабан) с улучшенными показателями фармакокинетики и фармакодинамики, позволившими им уверенно занять нишу среди пероральных антикоагулянтов и составить достойную конкуренцию варфарину.

Цель исследования: изучение объемов розничных продаж пероральных антикоагулянтных препаратов в г. Волгограде за 2014 г в сравнении с кварталами 1-3 2015 г.

Материалы и методы: материалами исследования явились результаты розничных продаж лекарственных средств в г. Волгоград за 2014 г. и 1-3 кварталы 2015 г. Группу изучаемых лекарственных препаратов составили антагонисты витамина К (код по анатомо-терапевтически-химической (АТХ) классификации - В01АA): фениндион (В01АА02), варфарин (В01АА03), аценокумарол (В01АA07); прямые ингибиторы тромбина (B01AE): дабигатрана этексилат (B01AE07) и прямые ингибиторы Ха фактора свертывания (B01AF): ривароксабан (B01AF01) и апиксабан (B01AF02). Оценивались следующие показатели: доля розничных продаж в российских рублях и сумма упаковок.

Результаты: объем розничных продаж антикоагулянтов непрямого действия и новых пероральных антикоагулянтов в 2014 году в денежном выражении составил 21567932 рубля, при этом на долю дабигатрана этексилата пришлось 51,49\%, ривароксабана - 38,49\%, варфрарина 8,92\%, френиндиона - 1,06\%, аценокумарола - 0,02\% и апиксабана 0,02\%. За первые три квартала 2015 г. розничный рынок продаж вырос до 23309441 рублей, структура которого представлена следующим образом: ривароксабан - 47,19\%, дабигатрана этексилат - 45,09\%, варфарин - 6,7\%, фениндион - 0,96\%, апиксабан - 0,06\%. Аценокумарол за первые девять месяцев 2015 г. продан не был.

Анализируя полученные данные, следует заключить о том, что прирост объема розничных продаж почти на 2 млн рублей может быть связан с увеличением доли ривароксабана на 8,7\% в денежном выражении. Стоит учесть тот фракт, что 2015 г. представлен только первыми тремя кварталами, и прирост может быть еще более выраженным.

В натуральном выражении рынок розничных продаж изучаемых лекарственных препаратов составил 23486 упаковок за 2014 г.: 51,02\% - варфарин, 21,15\% - дабигатрана этексилат, 13,86\% - фениндион, 13.81\% - ривароксабан, 0,14\% - аценокумарол, 0,02\% - апиксабан. В 2015 г. было продано 20687 упаковок, среди которых 50,31\% прищлось на варфарин, $21,95 \%$ - на дабигатрана этексилат, 19,04\% - на ривароксабан, 8,67\% - на фенилин, 0,03\% - на апиксабан.

С учетом того, что данные за 2015 г. представлены только за первые девять месяцев, можно с высокой долей вероятности предположить, что в натуральном выражении также будет положительный прирост розничных продаж. По результатам продаж в упаковках, варфарин занимает 1/2 от всех пероральных антикоагулянтов, что можно объяснить его доступностью для пациентов. Отмечается тенденция к увеличению доли новых пераральных антикоагулянтов с 35\% в 2014 г до 41\% в 2015 в основном за счет прироста доли ривароксабана на 5,23\%.

Заключение: отмечается положительный прирост рынка розничных продаж пероральных антикоагулянтов в г. Волгоград. Прямой ингибитор Ха свертывания крови ривароксабан показал положительные приросты как в денежном $(8,7 \%)$, так и в натуральном $(5,23 \%)$ выражениях. 